\title{
Polyphase deformation and garnet growth in pelitic schists of Sausar Group in Ramtek area, Maharashtra, India: A study of porphyroblast-matrix relationship
}

\author{
A Chattopadhyay and N Ghosh* \\ Department of Geology, University of Delhi, Delhi 110 00\%, India. \\ *e-mail: ng1704@rediffmail.com
}

\begin{abstract}
Polyphase deformation and metamorphism of pelitic schists of Chorbaoli Formation of Sausar Group in and around Ramtek area, Nagpur district, Maharashtra, India has led to the development of garnet and staurolite porphyroblasts in a predominantly quartz-mica matrix. Microstructural study of oriented thin sections of these rocks shows that garnet and staurolite have different growth histories and these porphyroblasts share a complex relationship with the matrix. Garnet shows at least two phases of growth - first intertectonic between $\mathrm{D}_{1}$ and $\mathrm{D}_{2}$ (pre- $\mathrm{D}_{2}$ phase) and then syn-tectonic to post-tectonic with respect to $\mathrm{D}_{2}$ deformation. Growth of later phase of garnet on the earlier (pre- $\mathrm{D}_{2}$ ) garnet grains has led to the discordance of quartz inclusion trails between core and rim portion of the same garnet grain. Staurolite develops only syn- $\mathrm{D}_{2}$ and shows close association with garnet of the later phase. The peak metamorphic temperature thus coincided with $\mathrm{D}_{2}$ deformation, which developed the dominant crenulation schistosity $\left(\mathrm{S}_{2}\right)$, regionally persistent in the terrain. The metamorphic grade reached up to middle amphibolite facies in the study area, which is higher than the adjoining southern parts of Sausar Fold Belt.
\end{abstract}

\section{Introduction}

Porphyroblasts are a valuable source of information on deformation and metamorphic evolutionary history of rocks. Porphyroblasts with inclusion patterns contain information on the nature of deformation and on the relative age of mineral growth and deformation. It is therefore usually advantageous to decipher the porphyroblastmatrix relationship in metapelites (and metabasites, especially if they are garnet-bearing) in any area for large-scale tectonic studies.

Microstructural studies of inclusions in porphyroblasts by numerous workers have led to the conclusion that they are mostly included in a 'passive' manner, without being significantly displaced by the growing porphyroblasts (Zwart 1962; Vernon 1975, 1976; Bell 1985; Barker 1994). In most cases, and especially at low to medium-grade metamorphism, minerals that do not participate in the metamorphic reaction are not removed completely from the reaction site because of slow diffusion rates, and are overgrown and enclosed by porphyroblasts as 'passive' inclusions (Passchier and Trouw 2005, p. 191). If the matrix around the growing porphyroblasts had a compositional layering or a shape prefered orientation of grains, this fabric may be partly preserved when grains are included in the porphyroblasts leading to an inclusion pattern, which mimics the pre-existing fabric.

Understanding the timing of porphyroblast growth relative to the development of surrounding metamorphic foliations is a fundamental requirement for useful applications of porphyroblast microstructures in regional deformationmetamorphic studies (Passchier and Trouw 2005). Porphyroblasts which are formed prior to a specific deformation episode ('pre-tectonic'

Keywords. Sausar Belt; porphyroblast-matrix relationship; crenulation cleavage; microstructural study. 
prophyroblasts) generally show strong deflection of matrix foliation around the porphyroblast that indicates the pre-existence of the 'rigid' grain prior to the deformation causing the development of the marix foliation (Zwart 1962; Vernon 1976; Yardley 1989; Barker 1998). Intertectonic porphyroblasts grow passively over a fabric in the absence of deformation and protect the resulting inclusion pattern from later deformations. Syntectonic porphyroblasts grow during an on-going phase of deformation. Inclusion patterns in such cases are usually curved and continuous with the matrix foliations outside the porphyroblasts and show evidence of having been rotated and/or reoriented during porphyroblast growth. Porphyroblasts grown after cessation of deformation are termed as 'post-tectonic'. The inclusion pattern within post-tectonic porphyroblasts is identical to and continuous with the external fabric (see Box 7.1 and figure 7.9 of Passchier and Trouw 2005). However, it should be kept in mind that the inclusion trail geometry observed in thin sections is essentially two-dimensional and depends on the position and orientation of the plane of section with respect to the porphyroblast. Great care should be taken to orient the sections at a high angle to the porphyroblast rotation axis and should be cut ideally through the porphyroblast near its centre (Powell and Treagus 1970; Busa and Grey 1992). In areas of repeated deformation and metamorphism, the angular relationship between the inclusion trails preserved in the porphyroblasts (internal schistosity $-S_{i}$ ) and the matrix foliation (external schistosity $-S_{e}$ ) provides key evidences for understanding the nature of the superposed deformational and metamorphic events. A discordant relation between the inclusion trails preserved in the core and those near the rim of the same porphyroblast may indicate metamorphic mineral growth overlapping more than one of the discrete deformation phases (Bell and Rubenach 1983; Passchier and Trouw 2005, p. 200-201). However, there has been strong disagreement and animated debate over the geological significance of strongly curved $S_{i}$ trails in porphyroblasts, especially the so-called 'snow-ball' inclusion patterns. One group of workers (Bell 1985; Bell and Johnson 1989; Bell et al 1992a, 1992b; Hickey and Bell 1999) have strongly argued that porphyroblasts do not rotate with respect to an external frame of reference and that even 'snow-ball' type spiral inclusion trails can be reinterpreted as a product of repeated overprinting deformation and transposition of the matrix foliation around a growing and non-rotating porphyroblast. The other group supports the existing and 'traditional' view of rotation of porphyroblasts in non-coaxial flow to explain strongly folded and rotated inclusion trails in porphyroblasts (Schoneveld 1979; Vernon 1988; Busa and Grey 1992; Visser and Mancktelow 1992; Passchier et al 1992; Williams and Jiang 1999; Jiang and Williams 2004). However, there is an inherent ambiguity in the interpretation of spiral inclusions by either rotation and non-rotation models (Johnson 1993a, b). A comprehensive review of the vast literature on this issue is beyond the scope of this paper and the attention of the interested reader is drawn to the up-to-date review in Passchier and Trouw (2005, p. 211).

In the present contribution we attempt to decipher the history of deformation and metamorphic mineral growth in the pelitic/semipelitic schists of polydeformed and metamorphosed Sausar Fold Belt in and around Ramtek area through the study of inclusion patterns in garnet and staurolite porphyroblasts. The angular relation of foliations in porphyroblasts and matrix $\left(S_{i}-S_{e}\right)$ and also in the core and rim portions of garnet porphyroblasts are studied in detail to understand the multi-stage growth of garnet which took place at least during two deformational events.

\section{Regional geology}

The Sausar Fold Belt (SSFB) is an important constituent of the Central Indian Tectonic Zone (CITZ) - a crustal-scale Precambrian mobile belt running E-W through the Indian Peninsular Shield (Radhakrishna and Naqvi 1986) (figure 1). SSFB is Meso- to Neoproterozoic in age (Sarkar et al 1986; Lippolt and Hautman 1994; Roy et al 2006) and comprises two major lithotectonic ensembles, viz., Tirodi Biotite Gneiss and migmatite (TBG) and metasedimentary Sausar Group (SSG). Lithologically, SSG represents a cratonic assemblage of metamorphosed quartzite, pelites and carbonate (cf. QPC assemblage of Condie 1989). TBG, on the other hand, refers to the gneissic and plutonic igneous rocks including granite gneiss, tonalite-trondjhemite gneiss, granodiorite gneiss, etc., with enclaves of older, high-grade supracrustals (Bhowmik et al 1999; Chattopadhyay et al 2001). The lithofacies distribution in the belt indicates progressive deepening of the basin towards the north (Chattopadhyay et al 2003a).

The Sausar supracrustal rocks have undergone polyphase deformation encompassing a single cycle of metamorphism (Bhowmick et al 2000; Chattopadhyay et al 2001; Roy and Prasad 2001). The dominantly E-W structural trend in SSFB is a result of the combined effect of the first three phases of deformation $\left(\mathrm{D}_{1}, \mathrm{D}_{2}, \mathrm{D}_{3}\right)$. First deformation occurred by a low angle thrusting, which led to the tectonic interleaving of basement and 


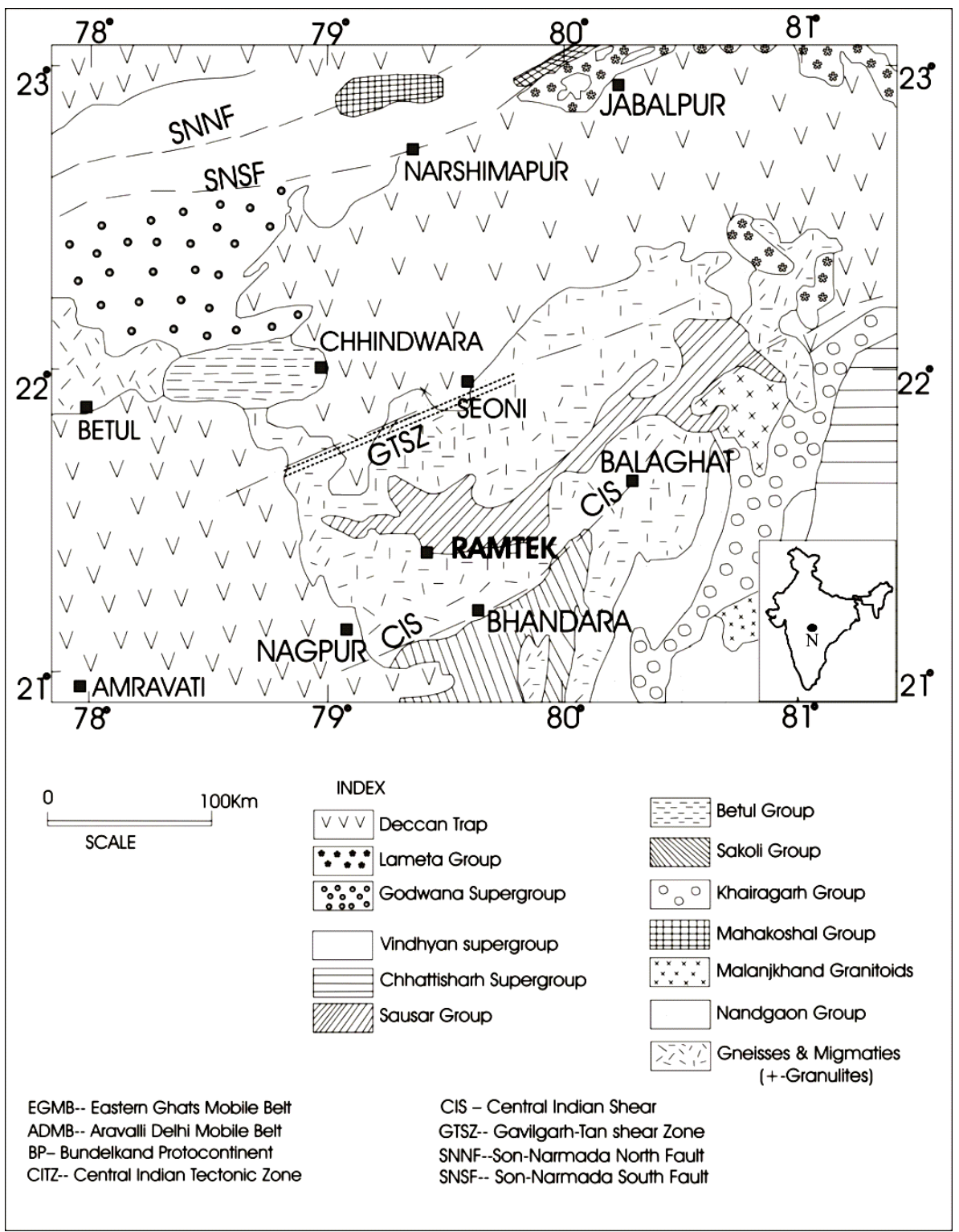

Figure 1. Geological map of part of central Indian shield showing position of Sausar belt (after Roy and Prasad 2001). Inset: Map of India showing position of study area ( $\mathrm{N}=$ Nagpur).

supracrustal rocks (Chattopadhyay et al 2001, 2003b). It also resulted in diversely-oriented, smallscale, tight-to-isoclinal, recumbent-to-reclined folds $\left(F_{1}\right)$ with axial planar foliation $\left(S_{1}\right)$. The second phase of folding produced upright-to-steeply inclined plane non-cylindrical folds $\left(\mathrm{S}_{2}\right)$ which also folded the thrust plane. $\mathrm{F}_{3}$ folds were upright in nature with low easterly plunging axes and consistently fold the $\mathrm{L}_{2}$ lineation. $\mathrm{F}_{4}$ developed only as weak 'cross-folds' on N-S striking axial plane (Chattopadhyay et al 2003a). The basement gneisses also participated in the deformation and were co-folded with the supracrustal rocks at many places. The metamorphic grade in the Sausar supracrustal rocks vary from greenschist to upper amphibolite facies with gradual increase in the grade of metamorphism from east-southeast to northwest (Narayanaswamy et al 1963; Bhowmik et al 1999). However, the gneissic rocks adjacent to the Sausar Group in the north and south contain enclaves of pelitic and basic granulites, overprinted by a retrograde amphibolite facies fabric (Bhowmik et al 1999). Recent geochronological study has indicated that the Sausar Fold Belt experienced a major tectonothermal event around 850-950 Ma (Rb-Sr WR-cum-mineral isochron) (Roy et al 2006). The above tectonothermal event imprinted an amphibolite facies fabric over a c. $1100 \mathrm{Ma}$ granulite grade foliations in the high grade quartzofeldspathic gneisses of the TBG suite. Sausar Belt therefore exhibits the latest tectonothermal (broadly Grenvillian) event of the CITZ, and has an important bearing on the reconstruction of Rodinia Supercontinent. 
The present study of $S_{i}-S_{e}$ tectonites was undertaken in the southern part of SSFB, in and around Ramtek town located $50 \mathrm{~km}$ to the northeast of Nagpur city (figure 1). The study area exposes massive to flaggy quartzite with interbands of quartz-muscovite-garnet-staurolite schist of the Chorbaoli Formation, forming high hills and ridges around Ramtek. This unit overlies the manganese-bearing sericite-muscovite-quartz schist of the Mansar Formation. The famous Kandri-Mansar group of manganese mines occurs towards the west of the study area. The quartzitemica schist units of Ramtek area, like many other parts of SSFB, exhibit four phases of folding. The first three of these $\left(F_{1}\right.$ to $\left.F_{3}\right)$ are nearly co-axial, but non-coplanar. $\mathrm{F}_{1}$ folds are rootless, tight-to-isoclinal recumbent/reclined folds. Generally recumbent or reclined folds were found in the hinge zone of large-scale $\mathrm{F}_{2}$ folds while gently-tosteeply inclined $\mathrm{F}_{1}$ folds occur in $\mathrm{F}_{2}$ limbs, because of reorientation by regional $\mathrm{F}_{2}$ folding. First generation lineation $\left(\mathrm{L}_{1}\right)$ occurs mainly in the form of hinge lines of small-scale $F_{1}$ folds. $F_{2}$ folds define the regional map pattern, with $\mathrm{E}-\mathrm{W}$ to WNW-ESE striking, sub-vertical axial plane and shallow SE plunge (figure 2a, b). Second generation lineation $\left(\mathrm{L}_{2}\right)$ is mainly represented as intersection of $\mathrm{S}_{0} / \mathrm{S}_{1}$ and $\mathrm{S}_{2}$, and occasionally as a mineral lineation defined by quartz and mica. $\mathrm{L}_{2}$ lineations are generally parallel to $\mathrm{F}_{2}$ axes and plunge SE $\left(20^{\circ}\right.$ towards $\left.114^{\circ}\right) . \mathrm{F}_{3}$ folds trend $\mathrm{E}-$ $\mathrm{W}$ and plunge easterly $\left(12^{\circ}\right.$ towards $\left.96^{\circ}\right)$, making an anticlockwise acute angle with the general trend of the $\mathrm{F}_{2}$ fold axes (figure $2 \mathrm{a}, \mathrm{c}$ ). $\mathrm{F}_{4}$ occur as cross folds with $\mathrm{N}-\mathrm{S}$, sub-vertical axial plane (see Chattopadhyay et al 2003a for details). Metamorphic $\mathrm{P}-\mathrm{T}$ in this area is not quantified, but the overall grade is upper greenschist to middle amphibolite facies, represented by the mineral assemblage: muscovite-garnet-staurolite-quartz in the schists. Staurolite is found mostly as small and skeletal porphyroblasts in coarse-grained garnet muscovite schist (Chattopadhyay et al 2003a). One interesting field observation is that a large granite body has intruded the schistose rocks immediately underlying the quartzite-pelite sequence in the study area. Available field criteria clearly indicate that the granite emplacemant was syntectonic and coincided with the $\mathrm{D}_{2}$ deformation (Chattopadhyay et al 2003a).

\section{Microstructures of pelitic schists}

\subsection{Orientation of thin sections}

Tectonic interpretation of the observed inclusion patterns in porphyroblasts, as discussed above, greatly depends on the orientation of the section planes with respect to the porphyroblast rotation axis and the orientation of the matrix foliation (Powell and Treagus 1970; Busa and Grey 1992). In the case of non-coaxial deformation producing strong monoclinic shape symmetry in the rock, sections normal to the vorticity vector (rotation axis of porphyroblasts, if any) will give the maximum amount of information. Some workers, however, prefer serial sectioning at different angles to identify the foliation intersection axis (FIA) for the study of complex spiral inclusions in porphyroblasts (Bell and Chen 2002). In the present study we prepared thin sections perpendicular to the $\mathrm{S}_{2}$ foliation and parallel to the mineral lineation $\left(\mathrm{L}_{2}\right)$ as those give us the best option of observing a section perpendicular to the possible rotation axis. Complex spiral inclusion trails were not present in these rocks and more elaborate sectioning procedure was not necessary. The description and interpretation presented in this paper mostly used these oriented thin sections. However, we also prepared three mutually perpendicular sections of a few selected samples, to cross-check the results. As none of them led to any significant difference in our observation and interpretation, we consider that the sectional problem was not significant as far as the present interpretations are concerned.

\subsection{Microscopic observation}

\subsubsection{Mineral association}

The studied rocks are generally composed of quartz, muscovite, garnet, staurolite and opaque minerals in the decreasing order of abundance. Quartz grains are mainly in the form of subidioblastic to xenoblastic crystals of various sizes. At places there are elongated, strained quartz grains having a preferred orientation. Muscovite occurs in the form of flakes or tabular grains, aligned parallel to the schistosity. Some of them are kinked due to deformation. Inclusions of quartz are seen in muscovite grains. Garnet occurs as elongate as well as round-shaped porphyroblasts. They contain inclusion trails of quartz, staurolite, and muscovite. Occasionally subidioblastic to idioblastic prismatic crystals of staurolite, containing inclusion trails of quartz, are observed.

\subsubsection{Microstructure}

Microstructural features suggest that there are different generations of garnet growth from pre- $\mathrm{D}_{2}$ to post- $\mathrm{D}_{2}$ (or at least syn- $\mathrm{D}_{2}$ ) events. The internal schistosity $\left(S_{i}\right)$ in garnet is mostly correlated with regional first generation $\left(\mathrm{S}_{1}\right)$ cleavage in the garnetiferous quartz-mica schists. This schistosity is 


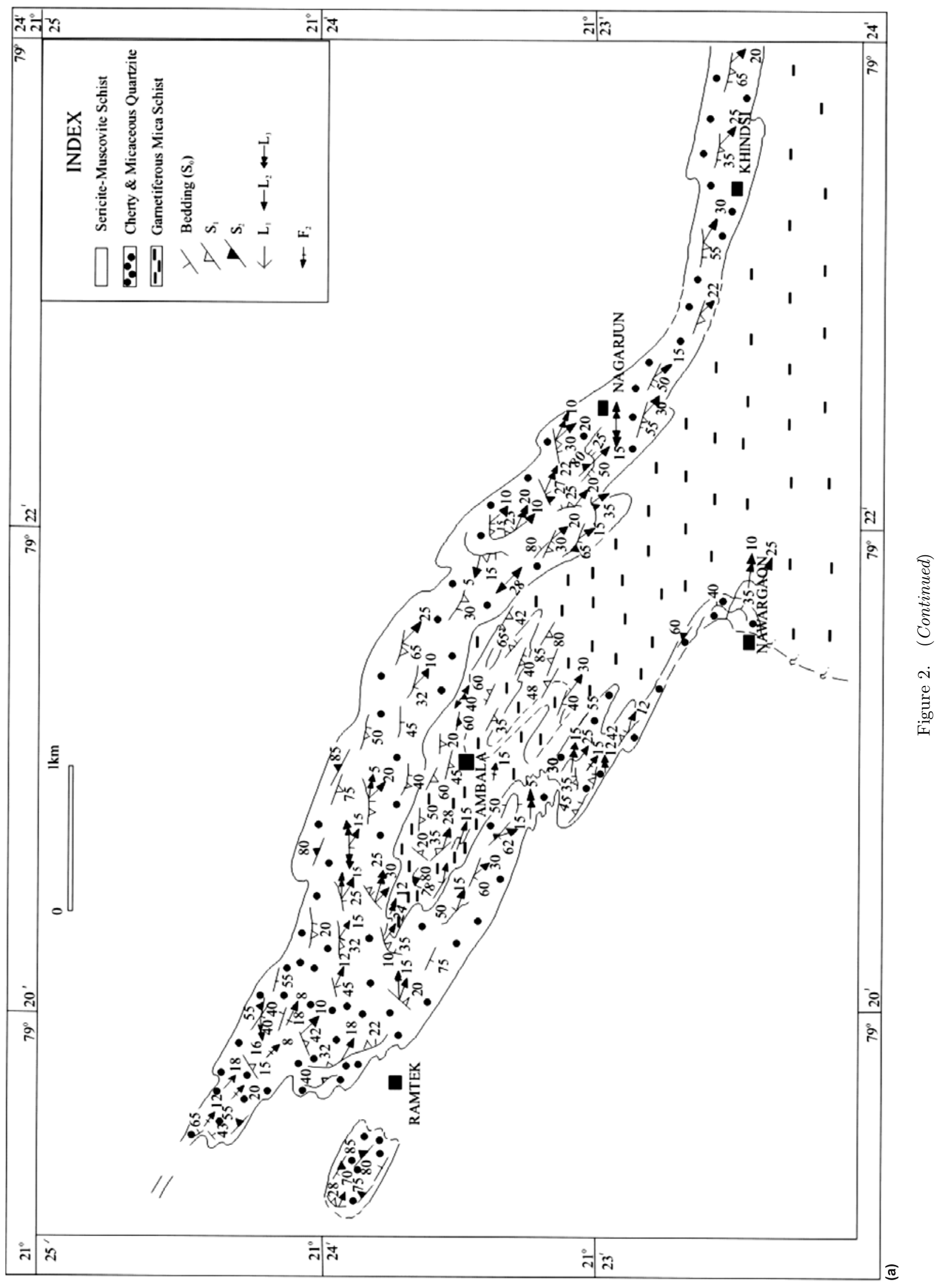




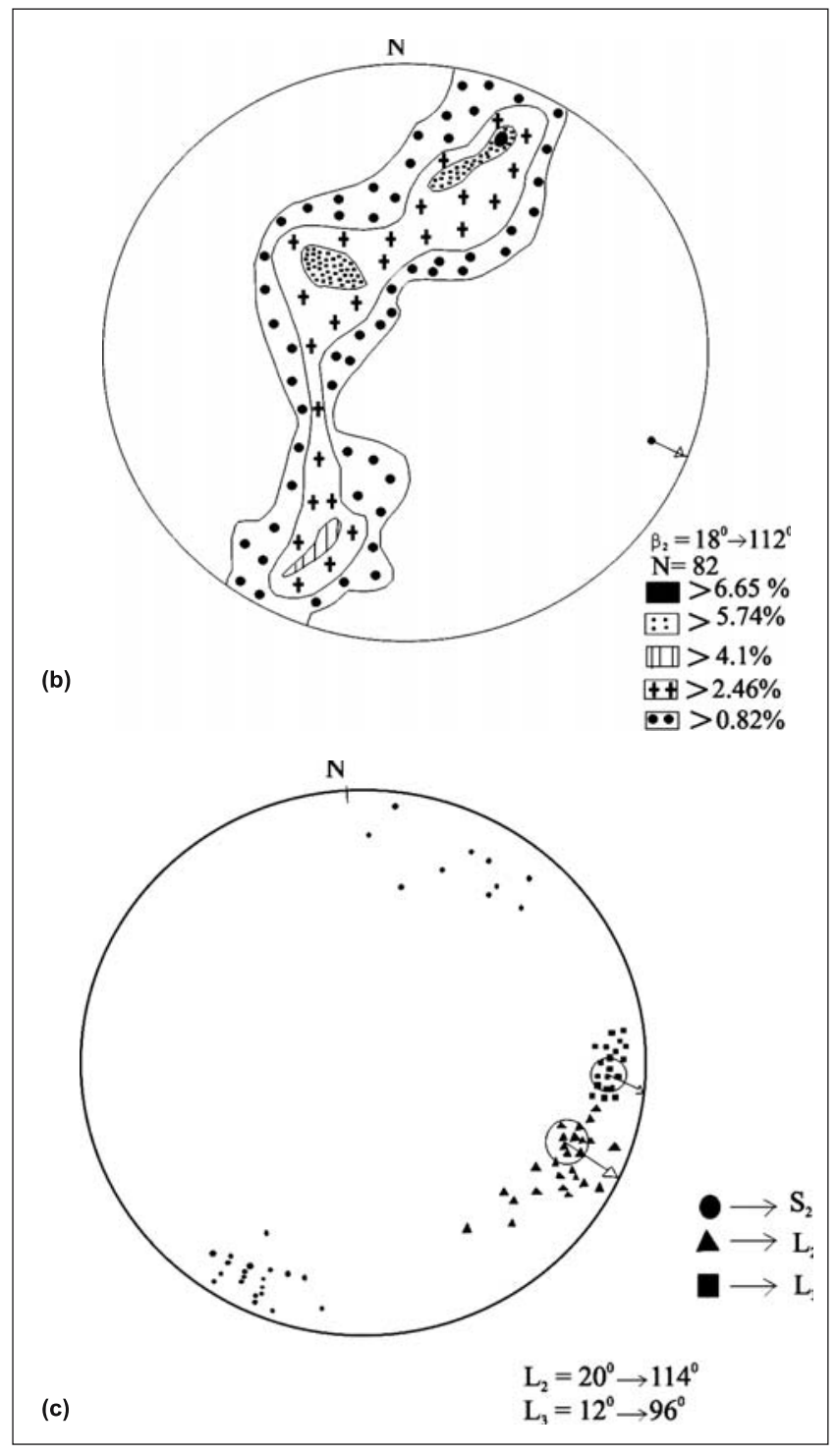

Figure 2. (a) Geological map of the study area showing Ramtek synform. (b) Lower hemisphere equal area projection (contoured) of poles to $\mathrm{S}_{0} / \mathrm{S}_{1}$ and the average regional $\mathrm{F}_{2}$ fold axis $(\beta)$. (c) Lower hemisphere equal area projection showing $\mathrm{L}_{2}, \mathrm{~L}_{3}$ and poles to $\mathrm{S}_{2}$.

regionally overprinted and transposed by a strong crenulation cleavage $\left(\mathrm{S}_{2}\right)$, which is clearly recorded in the microstructure of the schists.

Microscopic study of the quartz-mica schists shows a variety of relations between $S_{i}$ and $S_{e}$. Strong angular discordance between $S_{i}$ and $S_{e}$ and swerving of $S_{e}$ round the edge of an elongate garnet is observed in thin section (figure 3a). As $S_{i}$ is correlated with $\mathrm{S}_{1}$ and $S_{e}$ with $S_{2}$, this relation indicates at least pre- $\mathrm{D}_{2}$ origin of the garnet. Presence of coarse-grained quartz-rich pressure shadow region along the longer edges of the garnet confirms that garnet acted as a rigid grain during formation of $\mathrm{S}_{2}$ (figure $3 \mathrm{~b}$ ). A growth zonation is

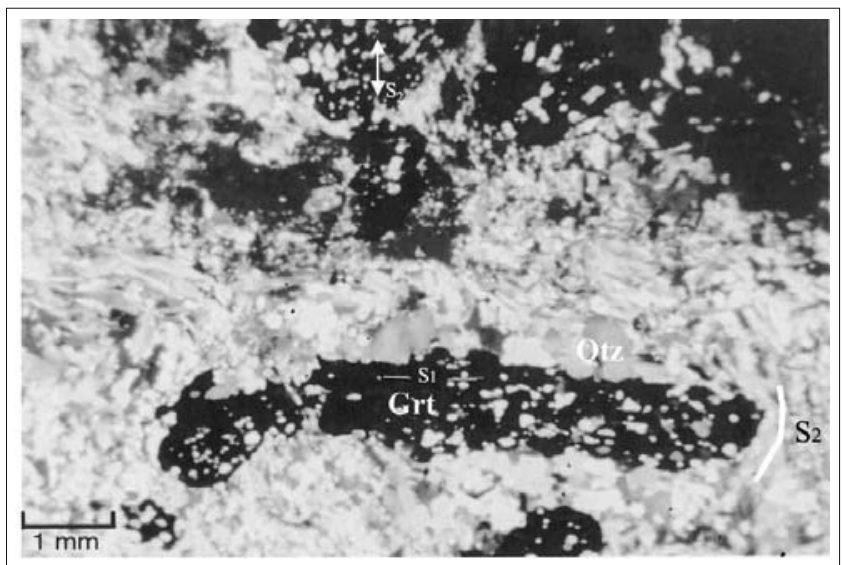

(a)

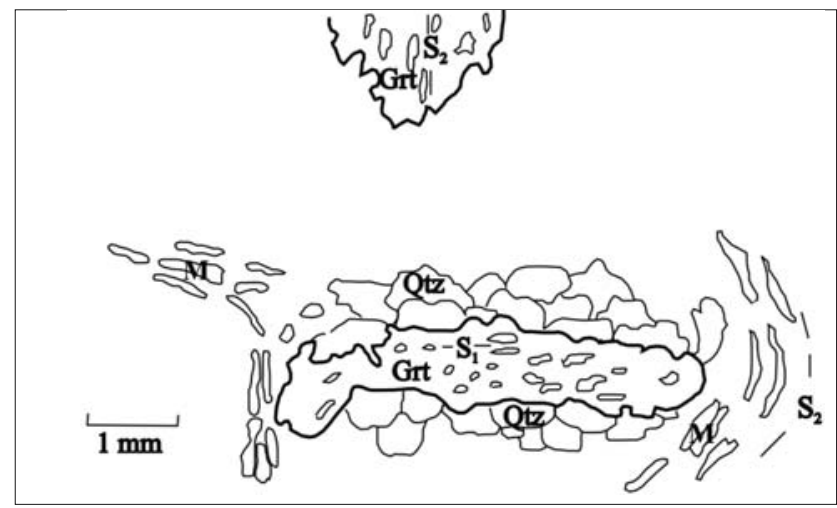

(b)

Figure 3. (a) Photomicrograph documenting the swerving of $\mathrm{S}_{2}$ round the edge of a garnet grain. Note that the rim portion of the garnet is idioblastic as it grew into the mica-rich strain-cap. (b) Sketch of the elongate garnet grain (Grt) shown in figure 3(a), showing quartz inclusions ( $\left.S_{i}=\mathrm{S}_{1}\right)$, pressure shadow zone quartz (Qtz), swerving of $\mathrm{S}_{2}$, formed by linear alignment of mica $(\mathrm{M})$, round the edges and another garnet (Grt) with inclusion trails $\left(S_{i}=\mathrm{S}_{2}\right)$ towards the top of the photograph.

apparent within the elongated garnet of figure 3(a), as the outermost part of the grain (to the right side) contains abruptly less number of quartz inclusions (compared to the core). The rim part of the garnet possibly grew over the mica-rich and quartzpoor strain cap part of $\mathrm{S}_{2}$, thereby having better crystallinity (much better developed euhedral outline) and lesser quartz inclusions. Therefore the core and rim portion of this garnet grain possibly has a time-separated growth history. Similar growth zonation is observed in the garnet shown in figure 4(a). The $S_{i}$ in the rim part is continuous and parallel to the $S_{e}$ but intersects the $S_{i}$ of the core part at a high angle. In the core part $S_{i}$ is also curved. The garnet shows microstructural features very similar to a 'deflection plane' (figure 7.32 of Passchier and Trouw 2005). Thus it is likely that 


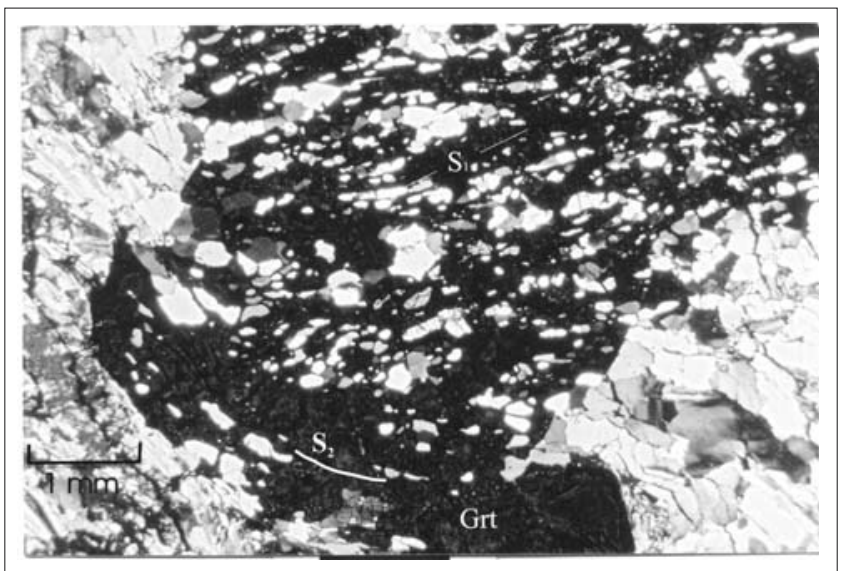

(a)

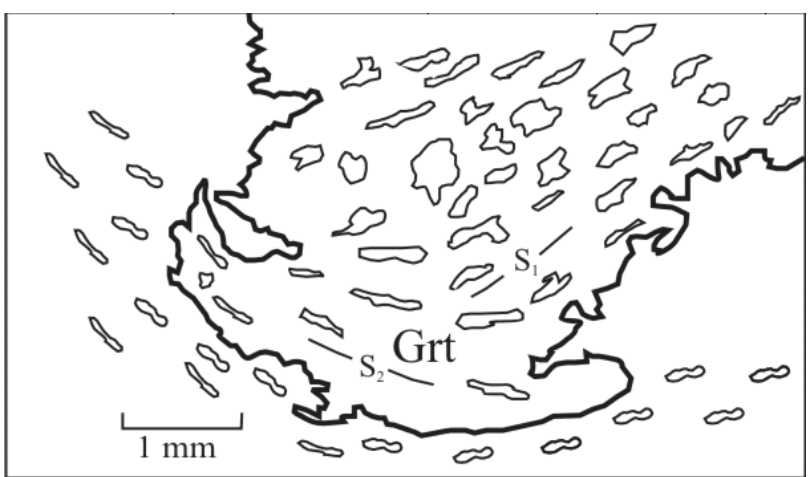

(b)

Figure 4. (a) Photomicrograph of quartz inclusion trails within the core of a garnet grain (Grt) $\left(S_{i}=\mathrm{S}_{1}\right)$ showing sharp discordance with those in the rim portion $\left(S_{i}=\mathrm{S}_{2}\right)$. Note the growth of garnet rim along $S_{2}$. (b) Schematic representation of figure $4(\mathrm{a})$, highlighting the microstructural relationship.

the core of the garnet grew over $\mathrm{S}_{1}$ during preto early syn- $\mathrm{D}_{2}$ deformation. During progressive $\left(\mathrm{D}_{2}\right)$ deformation there was a relative paracrystalline rotation between garnet and the matrix foliation, creating discordance between the orientation of $S_{i}$ and $S_{e}$. The rim of the garnet then overgrew $S_{e}\left(=\mathrm{S}_{2}\right)$ in the mica rich strain cap. Please note here that the relative rotation between $S_{i}$ and $S_{e}$ does not indicate that the porphyroblast has necessarily rotated (Ramsay 1962). Syn- $\mathrm{D}_{2}$ growth of garnet is also observed (figure 5a) where a garnet grain has trapped a weak $\mathrm{D}_{2}$ crenulation. Larger grains of quartz formed in the pressure shadow zone of the garnet are skeletally enclosed by growth of garnet in the later phases of $\mathrm{D}_{2}$. In the matrix, $\mathrm{S}_{2}$ shows broad wraps, possibly due to a later weak deformation $\left(\mathrm{D}_{3} / \mathrm{D}_{4}\right)$.

Occasionally, inclusions of idioblastic staurolite grains are observed within garnet porphyroblasts (figure 6a). Internal schistosity $\left(\mathrm{S}_{1}\right)$ within the garnet runs through the staurolite grains without any

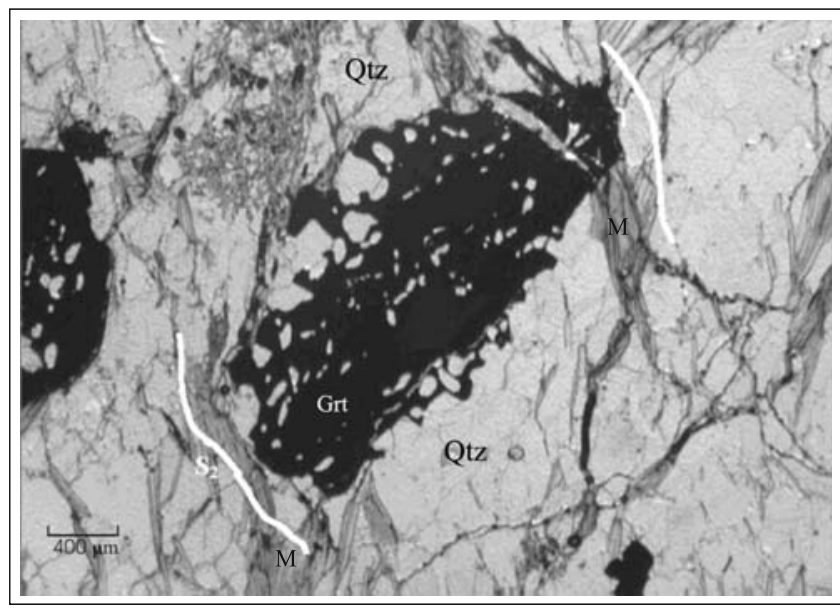

(a)

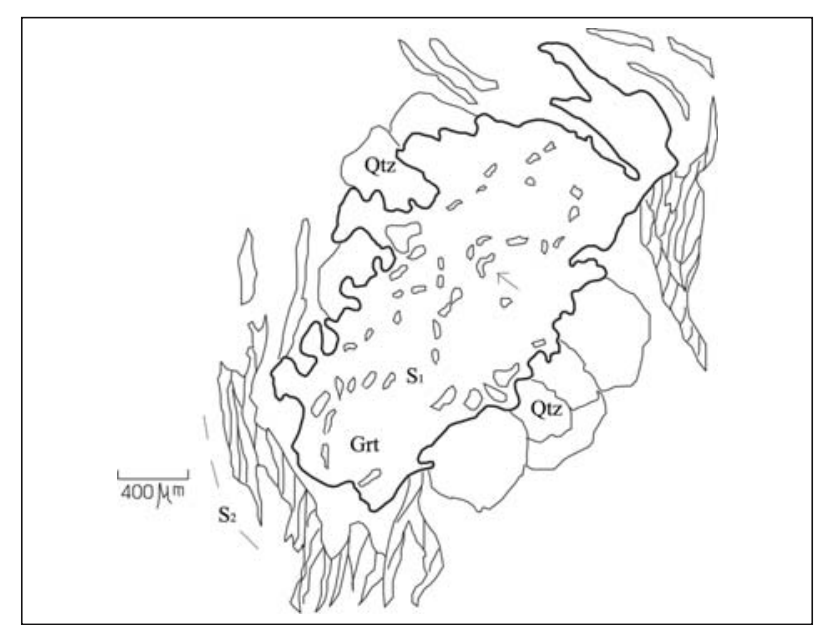

(b)

Figure 5. (a) Photomicrograph of a syn- $\mathrm{D}_{2}$ garnet porphyroblast (Grt) documenting weakly-crenulated internal foliation $\left(S_{i}=\mathrm{S}_{1}\right) . \mathrm{S}_{2}$ swerves round the garnet grain (white line). Qtz $=$ Quartz and $\mathrm{M}=$ Mica. (b) Schematic representation of figure 5(a). The arrow points to the internal crenulation.

significant deviation. $S_{i}$ is continuous with $S_{e}$ but it shows curvature around the garnet porphyroblast indicating that the garnet and staurolite may have overgrown $S_{2}$ followed by a relative rotation of $S_{i}$ and $S_{e}$.

\subsection{Deformation and porphyroblast growth history}

From the microstructural evidences described above, it is clear that the peak metamorphic condition saw the growth of garnet and staurolite in the pelitic schists of the Ramtek area. In the studied rocks, $D_{2}$ was a major crenulation event, which folded the $\mathrm{S}_{1}$ schistosity and completely transposed it in most parts of the rock. Garnet porphyroblasts formed either pre- $\mathrm{D}_{2}$ (figure $3 a$ ) or early syn- $\mathrm{D}_{2}$ (figure 5 ) trapping $\mathrm{S}_{1}$ as 


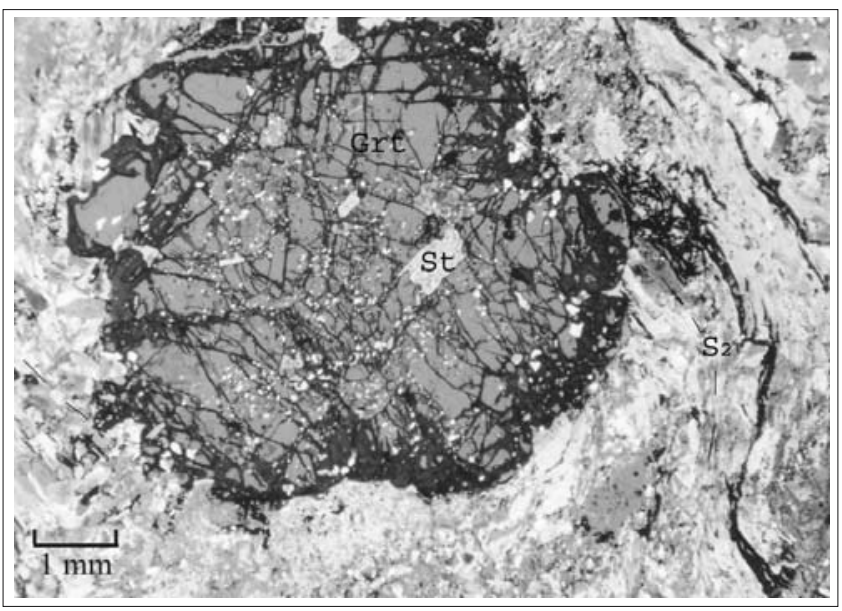

(a)

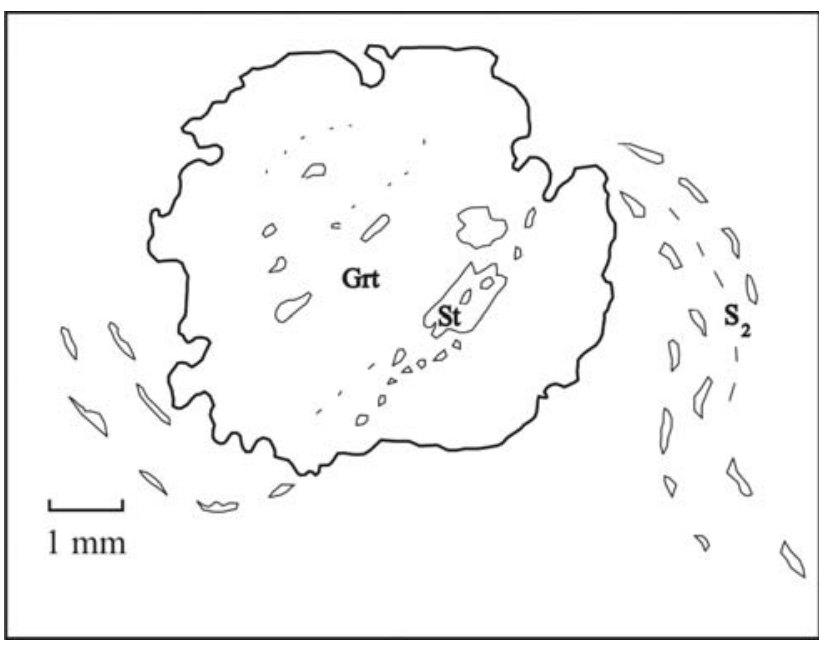

(b)

Figure 6. (a) Poikiloblastic intergrowth of garnet (Grt) and staurolite (St) and continuous curvature of matrix schistosity $\left(\mathrm{S}_{2}\right)$ within the garnet. The relative rotation between the garnet and the matrix foliation can be explained by rotation of either garnet (non-coaxial deformation) or the foliation (co-axial deformation). (b) Schematic representation of figure $6(\mathrm{a})$.

$S_{i}$. With ongoing deformation, $\mathrm{S}_{1}$ was completely transposed by the crenulation cleavage $\left(\mathrm{S}_{2}\right)$ in the matrix, but remained preserved within the porphyroblasts. This created a clear discordance and truncation between $S_{i}$ and $S_{e}$ of the garnet. $\mathrm{S}_{2}$ also swerved round the already rigid porphyroblasts and formed mica-rich 'strain caps' and coarse quartz-rich pressure shadow along two orthogonal faces of garnet (figures 3a, b). After this stage, garnet again started growing along the $\mathrm{S}_{2}$ planes. They have grown with euhedral outline in micarich strain-cap zones, with very few quartz inclusions (figures 3 and 4 ) or show skeletal growth of garnet in the quartz-rich pressure shadow zone (figure 5). Elsewhere syn- $\mathrm{D}_{2}$ garnet nucleated directly onto a $\mathrm{S}_{2}$ fabric and overgrew it (figures $3 \mathrm{~b}, 6$ ).
The syn- $\mathrm{D}_{2}$ growth phase has also resulted in the growth of inclusion-poor rim over an inclusionrich core of the garnet (figure 4) as described earlier. Limited evidences indicate a relative rotation between $S_{i}$ and $S_{e}$ between these two phases of garnet growth (figures 4,6 ), but it is hard to conclude, from these rather ambiguous evidences, whether it is the porphyroblasts or the matrix foliation which has actually rotated (Passchier and Trouw 2005, p. 213). Staurolite, on the other hand, grew only over $\mathrm{S}_{2}$ fabric and therefore is evidently syn- to post- $\mathrm{D}_{2}$. It is also interesting to note that staurolite is intimately associated with only those garnets having a late- $\mathrm{D}_{2}$ (or post- $\mathrm{D}_{2}$ ) growth phase (e.g., figure 6 ). The sharp, euhedral outline of staurolite included in garnet clearly indicates that they are not relicts of a reactant phase, but are produced alongwith garnet and possibly poikiloblastically enclosed later.

From the above discussion, it is evident that in the pelitic schists of Ramtek area, metamorphic grade went up to amphibolite facies, characterised by formation of garnet and staurolite along with biotite, muscovite and quartz. Garnet grew in two phases: first only garnet formed either intertectonic between $D_{1}$ and $D_{2}$, and/or during the early part of $\mathrm{D}_{2}$ deformation followed by another phase of garnet + staurolite growth during the later part of $\mathrm{D}_{2}$. Garnet of this later phase overgrew the earlier garnet cores at many places, giving a varied, and often discordant, relationship between $S_{i}$ and $S_{e}$. The schematic representations of the possible sequence of deformation vis-à-vis porphyroblast growth in different cases are illustrated in figure 7 .

\section{Discussion}

The regional $\mathrm{D}_{2}$ deformation in Sausar Belt is the major fold-forming event, as discussed earlier. In the study area, the garnetiferous schistose rocks used for the present study occur at the core of a map scale synformal $\mathrm{F}_{2}$ fold. The geometric analysis of outcrop scale $\mathrm{F}_{2}$ folds in the area indicate that $\mathrm{F}_{2}$ folds formed dominantly by flexure, without significant flattening (Chattopadhyay et al 2003a). Field evidences indicate that the kinematics of $\mathrm{D}_{2}$ deformation was dominantly co-axial except local non-coaxial flow in the larger $\mathrm{F}_{2}$ fold limbs. Frequent rotation of equant porphyroblasts during $\mathrm{D}_{2}$ deformation are therefore not expected, as it would be in a typical non-coaxial deformation zone. The majority of our microstructural interpretations indicate only relative rotation between porphyroblasts and the matrix. The observations from the studied samples are insufficient to make any general comments on the 'rotation' vs. 'nonrotation' debate. 


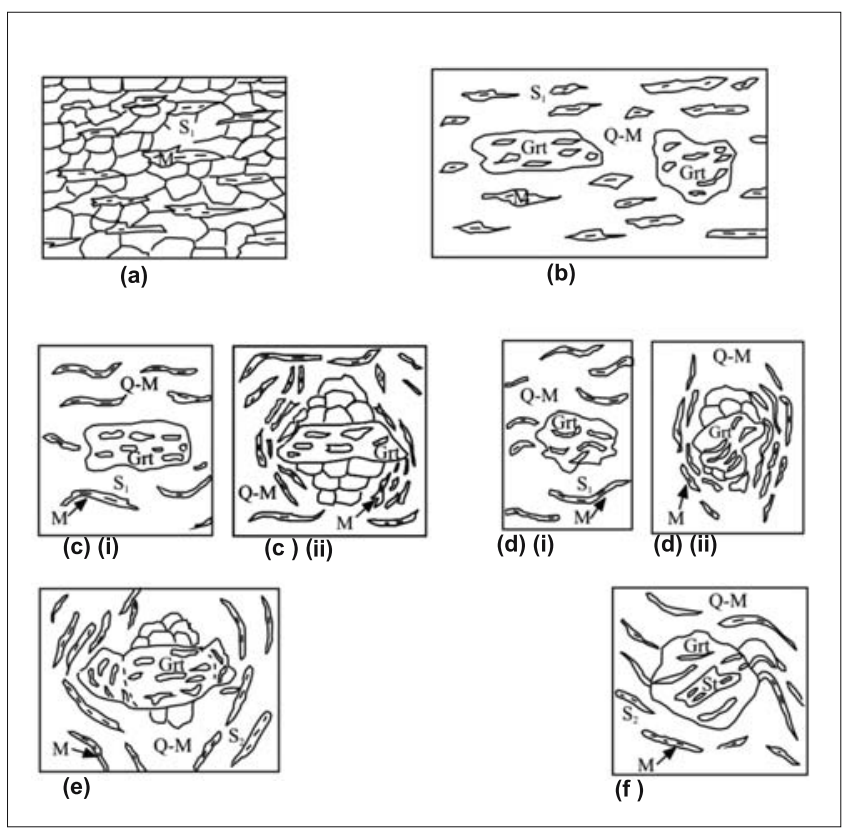

Figure 7. Schematic diagrams documenting the time-relationship between the deformation and porphyroblast growth in pelitic schists of the study area. Grt = Garnet, $\mathrm{Q}-\mathrm{M}=$ Quartz-Mica domain in the matrix, $\mathrm{M}=$ Mica. (a) Development of $\mathrm{S}_{1}$ schistosity (chl-mus-qtz?) in pelitic schist. (b) Garnet grows on $\mathrm{S}_{1}$ with straight quartz inclusions $\left(S_{i}=\mathrm{S}_{1}\right)$ in the quartz-mica (Q-M) domains. (c) The matrix schistosity $\left(S_{e}\right)$ gets crenulated and ultimately completely transposed to $S_{2}$, swerving round the pre-existing garnet grains (figure 3). Quartz forms in the pressure shadow zone. (d) Garnet grows prior to or synchronous with $\mathrm{D}_{2}$ crenulation event and gets curved internal trails $\left(S_{i}=\mathrm{S}_{1}\right)$. $S_{e}$ is transposed $\mathrm{S}_{2}$ (cf. figure 5). Note the mica-rich strain cap and quartz-rich pressure shadow zones around garnet. (e) Core and rim portion of garnet grew in two phases with discordant internal schistosity (figure 4). (f) Syn- $\mathrm{D}_{2}$ garnet and staurolite overgrowing the matrix schistosity $\left(\mathrm{S}_{2}\right)$ (figure 6 ). The microstructural features indicate a relative rotation between the porphyroblast and the matrix foliation. But whether the porphyroblast or the matrix actually 'rotated' cannot be ascertained from this. See text for discussion.

A major problem encountered during this study of $S_{i}-S_{e}$ tectonites in the pelitic schists of the Ramtek area is the altered nature of these rocks, which hindered any attempt to determine the chemical compositions of these garnets by Electron Probe MicroAnalysis. Another problem, as already discussed, is the absence of characteristic reaction textures in the studied samples which makes it difficult to constrain the metamorphic history of the area. Overall mineral association however indicates that metamorphic temperature must have reached amphibolite grade and this thermal peak more or less coincided with $\mathrm{D}_{2}$ deformation. Metamorphic signatures in the southern part of the Sausar Fold Belt generally indicate greenschist facies metamorphism. The cause of higher metamorphic grade in the studied area is yet to be worked out. Large volumes of syn- $\mathrm{D}_{2}$ granitoid intrusions found in the area may have a causal relation with this enhanced grade of metamorphism as a possible heat source. Future work should concentrate on this aspect of geology of the Sausar Group of rocks in and around Ramtek.

\section{Acknowledgements}

Department of Geology, Delhi University has partly provided the financial assistance for the work. The help rendered by Shri S Rallan during field work is acknowledged. We thank Shri Lalit Khasdeo, Shri Tamal Pal and Shri Raju Kumar for help at different stages of manuscript preparation. Sincere thanks to Prof. M Mamtani for a careful and constructive review of the manuscript and to Dr. J S Ray for helpful editorial advice.

\section{References}

Barker A J 1994 Interpretation of porphyroblast inclusion trails: limitations imposed by growth kinetics and strain rates; J. Metamorph. Geol. 12 681-694.

Barker A J 1998 Introduction to metamorphic textures and microstructures; $2^{\text {nd }}$ edn., Blackie, Glasgow.

Bell T H 1985 Deformation partitioning and porphyroblast rotation in metamorphic rocks: a radical reinterpretation; J. Metamorph. Geol. 3 109-118.

Bell T H and Rubenach M J 1983 Sequential porphyroblast growth and crenulation cleavage development during progressive deformation; Tectonophys. 92 171-194.

Bell T H and Chen A 2002 The development of spiral-shaped inclusion trails during multiple metamorphism and folding; J. Metamorph. Geol. 20 397-412

Bell T H and Johnson S E 1989 Porphyroblast inclusion trails: the key to orogenesis; J. Metamorph. Geol. 3 109-118.

Bell T H, Johnson S E, Davis B, Forde A, Hayward N and Wilkins C 1992a Porphyroblast inclusion-trail orientation data: eppure non son girate; J. Metamorph. Geol. 10 295-300.

Bell T H, Forde A and Hayward N 1992b Do smoothly curved, spiral-shaped inclusion trails signify porphyroblast rotation? Geology 20 59-62.

Bhowmik S K, Pal T, Roy A and Pant N C 1999 Evidence for Pre-Grenvillian high-pressure granulite metamorphism from the northern margin of the Sausar mobile belt in central India; J. Geol. Soc. India 53 385-399.

Bhowmik S K, Pal T, Roy A, Pant N C and Shome S 2000 Implication of Ramakona cordierite gneiss in the crustal evolution of Sausar mobile belt in Central India. Proc. Int. Seminar on Precambrian crust in Eastern and Central India, UNESCO-IUGS-IGCP-368; Geol. Surv. India Spec. Publ. 57 131-150.

Busa M D and Grey N H 1992 Rotated staurolite porphyroblasts in the Littleton Schist at Bolton, Connecticut, USA; J. Metamorph. Geol. 10 627-636.

Chattopadhyay A, Bandyopadhyay B K and Khan A S 2001 Geology and Structure of Sausar fold belt: A retrospection and some new thoughts; In: National Seminar on Recent Advances in the Field of Earth Sciences and their Implications in National Development; Geol. Surv. India Spec. Publ. 64 251-263. 
Chattopadhyay A, Khan A S, Huin A K and Bandyopadhyay B K 2003a Reinterpretation of stratigraphy and structure of Sausar Group of rocks in Ramtek-Mansar-Kandri area, Maharashtra, Central India; J. Geol. Soc. India 61 75-89.

Chattopadhyay A, Huin A K and Khan A S 2003b Structural framework of Deolapar area, central India, and its implications for Proterozoic nappe tectonics; Gondwana. Res. 6 107-117.

Condie K C 1989 Plate Tectonics and Crustal Evolution. $\left(3^{\text {rd }}\right.$ edn $)$. Pergamon Press.

Hickey K A and Bell T H 1999 Behaviour of rigid ductile objects during deformation and metamorphism: a test using schists from the Bolton Syncline, Connecticut, USA; J. Metamorph. Geol. 17 211-228.

Jiang D and Williams P F 2004 Reference frame, angular momentum, and porphyroblast rotation; J. Struct. Geol. $262211-2224$.

Johnson S E 1993a Unravelling the spirals: a serial thin section study and three-dimensional computer-aided reconstruction of spiral-shaped inclusion trails in garnet porphyroblasts; J. Metamorph. Geol. 11 621-634.

Johnson S E 1993b Testing models for the development of spiral-shaped inclusion trails in garnet porphyroblasts: to rotate or not to rotate, that is the question; J. Metamorph. Geol. 11 635-659.

Lippolt H J and Hautmann S 1994 Ar40/Ar39 ages of Precambrian manganese of ore minerals from Sweden, India and Morocco; Mineralium Deposita 30 246-256.

Narayanaswami S, Chakravarty S C, Vemban N A, Shukla K D, Subramaniam M R, Venkatesh V, Rao G V, Anandalwar M A and Nagrajiah R A 1963 The geology and manganese ore deposits of the manganese belt in Madhya Pradesh and adjoining parts of Maharashra. Part I: General Introduction; Bull. Geol. Surv. India A-22 (I).

Passchier C W and Trouw R A J 2005 Microtectonics. Springer-Verlag.

Passchier C W, Trouw R A J, Zwart H J and Vissers R L M 1992 Porphyroblast rotation: eppur si mouve? J. Metamorph. Geol. 10 283-294.
Powell D and Treagus J E 1970 Rotational fabrics in metamorphic minerals; Mineralogical Magazine 37 801-814.

Radhakrishna B P and Naqvi S M 1986 Precambrian continental crust and its evolution; J. Geol. 94 145-166.

Ramsay J G 1962 The geometry and mechanics of formation of "similar" type folds; J. Geol. 63 512-526.

Roy A and Prasad M H 2001 Precambrian of Central India: a possible tectonic model; Geol. Surv. India Spec. Publ. 64 177-197.

Roy A, Kagami H, Yoshida M, Roy A, Bandopadhyay B K, Chattopadhyay A, Khan A S, Huin A K and Pal T 2006 $\mathrm{Rb}-\mathrm{Sr}$ and $\mathrm{Sm}-\mathrm{Nd}$ dating of different metamorphic events from the Sausar Mobile Belt, central India: implications for Proterozoic crustal evolution; J. Asian Earth Sci. 26 $61-76$.

Sarkar S N, Trivedi J R and Gopalan K 1986 Rb-Sr whole rock and mineral isochron age of the Tirodi Gneiss, Sausar Group, Bhandara district, Maharashtra; J. Geol. Soc. India 27 30-37.

Schoneveld C 1979 The geometry and significance of inclusion patterns in syntectonic porphyroblasts. PhD thesis, Leiden State University.

Vernon R H 1975 Deformation and recrystallisation of a plagioclase grain; American Mineralogist 60 884-888.

Vernon R H 1976 Metamorphic processes. Allen and Unwin, London.

Vernon R H 1988 Microstructural evidence of rotation and non-rotation of mica porphyroblasts; J. Metamorph. Geol. 6 595-601.

Visser P and Mancktelow N S 1992 The rotation of garnet porphyroblasts around a single fold, Lukmanier Pass, Central Alps; J. Struct. Geol. 14 1193-1202.

Williams P F and Jiang D 1999 Rotating garnets; J. Metamorph. Geol. 17 367-378.

Yardley B W D 1989 An introduction to metamorphic petrology. Longman Earth Science Series, Wiley, New York.

Zwart H J 1962 On the determination of polymetamorphic mineral associations, and its application to the Bosost area (central Pyrenees); Geol. Rdsch 52 38-65. 